\title{
The Factors Influence Intention to Use Mobile Payment in Jakarta
}

\author{
Ririn Wulandari ${ }^{1}$, Ehrse Dwi Winastyo ${ }^{2}$ \\ \{ririn.wulandari@mercubuana.ac.id ${ }^{1}$,ehrse.dwi@gmail.com² ${ }^{2}$, \\ Universitas Mercu Buana, Jakarta, Indonesia ${ }^{12}$
}

\begin{abstract}
Competition between the mobile payment industry in Indonesia from 2017 has been very tight. It is necessary to conduct research on consumer behavior in choosing and using m-payments, in order to compete. This study aims to determine the effect of perceived ease of use, perceived usefulness, perception of mobility, and perceived trust on intention in using mobile payments in Jakarta. The research analysis used multiple linear quantitative analysis. The population of this study is consumers who have used mobile payments and have the intention to use the services. Determination of the number of samples using the Hair theory, because the number of populations is not known precisely. The sample totaled 124 respondents. The results show that there is a significant and positive influence between perceived ease of use, perceived usefulness, perceived mobility, and perceived trust on interest in using mobile payments. The basic concept of TAM Theory is 2 variables of behavior and consumer perceptions of technological change, perceived ease of use, and perceived usefulness. The results of this study are the development of this theory by adding perceive mobility and perceived trust as behaviors and perceptions that influence the intention to use the technology, in this case, mobile payment technology.
\end{abstract}

Keywords: TAM, Perceive Mobility, Perceive Trust

\section{Introduction}

Report data on articles on the MDI (Metra Digital Innovation) Ventures and Mandiri Sekuritas website published in early 2018[1] show that the pioneer of mobile payment (mpayment) applications in Indonesia is T-Cash, thus T-Cash has been the leader in its market since its establishment in 2007 to 2017. In 2017 GoPay appeared in a package with Go-Jek shifting the position of T-Cash. Base on the iprice group research in 2019 [2] The presence of Go-Jek, as an online transportation provider platform, raises the need for mobile payments, so that GoPay users also increase along with the increase in Go-Jek users. Likewise, the presence of the OVO mobile payment as part of Grab's online transportation payment tool. Even though in 2017 until the second quarter, OVO was not yet superior to TCash, being ranked 3rd after T-Cash. In the 3rd quarter of 2018 to the first quarter, T-Cash was still in 3rd place, but in the 2nd quarter of 2019. The position of T-Cash which was ranked 3rd was evicted by Dana and also after changing its name to LinkAja.

There is intense competition in the m-payment industry [2]. In the future, the use of $\mathrm{m}$ payment is increasingly needed, especially in the face of the Industrial Revolution 4.0 era, as well as dealing with conditions during the Covid 19 Pandemic, as well as after the pandemic. Where, all activities need to follow health protocols, including maintaining physical 
interaction distance. In maintaining distance, offline buying and selling transactions need to be done by minimizing the use of cash (cashless) [3], as well as online transactions, so that the use of m-payments is expected to be more widespread. This has prompted banks to issue $\mathrm{m}$-payments, both individually and collectively. Base on report of alvara research LinkAja is an m-payment application issued by Telkomsel together with Bank Mandiri, Bank BRI, Bank BNI, and Bank BTN. M-payment consists of two types, namely the value of money stored electronically in the form of chips and in the form of servers. In this research, what is meant by m-payment is the value of money stored in the form of a server.

Based on the explanation above, the existence of intense competition in the m-payment industry, it is necessary to conduct research on consumer behavior in choosing and using $\mathrm{m}$ payments, namely the factors that can influence customer interest in using m-payments. Previous researchers, Liu et al. (2019) [4] state that there are 5 (five) factors that influence the interest in using mobile payments, perceived mobility, perceived ease of use, perceived usefulness, perceived risk. (perceptions of use risks) and perceived costs (perceived costs of using services). In addition, the factors in the Technology Acceptance Model (TAM) method that are often used in research are measured in terms of consumer behavior and perceptions. (Ahmad et al. 2016) [5].

Another opinion says that the factors that influence interest in using GoPay m-payments in Indonesia are perceptions of usefulness, perceived ease of use, mobility, attitudes, and reputation of m-payments. However, the perception of trust (trust) does not have a significant effect (Chandra et al. 2018) [6]. In addition, other researchers argue that the factors that influence the acceptance of the use of mobile payments such as E-wallets are perceived ease of use, perceived usefulness, subjective norms, perceived trust and perception self-efficacy and behavior (Trivedi, 2016) [7].

On the other hand, the preliminary survey results show that factors that influence the intention to use m-payments, the first is ease of use, the second is to provide benefits and usefulness, the third is the m-payment application that can be used anywhere by users (mobility), the fourth is trust for the m-payment application, the fifth is the use of m-payment is influenced by personal motivation, the sixth is that the use of the m-payment application costs money, the seventh is the use of m-payment is risky (risk), and the eighth is the use of $\mathrm{m}$-payment is influenced by friends / relatives (social influence).

Based on the results of previous research and preliminary survey results, it is determined that the independent variables will be tested in influencing the intention to using $\mathrm{m}$ payments, so that the purpose of this study is to determine the effect of perceived ease of use, perceived usefulness and perceived mobility of use, and user trust, on intention to use Mobile Payment.

The TAM theory describes that the perceived benefits and convenience are the basic determining factors for technology acceptance. These two basic beliefs underlie the formation of attitude and behavior (Davis, 1989) [8]. Perception ease of use (ease of use) is defined as the extent to which a person believes that using a technology results in convenience (Davis, 1989 [8]; Jogiyanto 2007 [9]). Thus, the perception ease of use in this case is that the customer's trust in using m-payments will reduce difficulties and lead to easeof-use transactions. Perceived usefulness is a level where a person believes that a certain use of technology will increase the person's work performance (Davis 1989 [8]; Jogiyanto 2007 [9]; Adamson and Shine 2003 [10]; Venkatesh and Morris 2003) [11].

The perception of convenience in this case is the customer's perception that by using $\mathrm{m}$ payment, customers can be more productive and efficient in using their time. According to previous researchers, perceptions ease of use and perceptions of usefulness have a significant 
effect on interest in using or purchase intentions (Fitri and Wulandari 2020 [12]; Liu et al. 2019[4]; Rahim 2019 [13]; Meiranto 2016 [14], Mandariza et al. 2019 [15]; Chandra et al. 2018 [6]; Arfan and Mirza, 2020 [24]). Mobility is the ability to access services anywhere and anytime (Pal et al. 2015) [14] or a determinant used to measure the benefit that a person receives in the context of the benefit of time, space and service access (Tai and Liu, 2015) [15]. Several previous researchers determined that mobility factors became the emergence of interest in using mobile payments (Liu, et al. 2019 [4]; Chandra, et al. 2018 [6]; Schierz, et al. 2010 [18]).

Trust related to the belief that the trusted party will fulfill its commitment (Gefen et al. 2003) [19], or trust as an assessment of a person's relationship with another person who will carry out certain transactions according to expectations in an environment full of uncertainty (Ba and Pavlou, 2002) [20]. Several researchers found that the perception of trust affects the interest in using mobile payments. The perceived factor of trust (trust) can be different between the results of research in India with the United States and China, where research in India, the perceived factors of trust and self-efficacy have no significant effect on the use of e-wallet payments according to (Trivedi, 2016) [7], but in the United States and Chinese perceptions of security and trust factors can influence user attitudes towards mobile payment (Fan, et. al. 2018) [21].

In addition, the results of other researchers indicate that the perception of trust affects customer behavior in using mobile payments (Mandariza, et al. 2019 [15]; Ahmad, et al. 2016 [5]; Yang, 2015 [22]; Arfan and Mirza, 2020 [24]). Contrary to the results of this study, there is an opinion stating that the perceived trust factor does not affect the interest in using mobile payments (Chandra, et al. 2018 [6]; Schierz, et al. 2010) [18].

\section{Research Method}

The research analysis used multiple linear quantitative analysis. The study population is consumers who have used mobile payments and have intention to use the services for financial transactions. Determination of the number of samples using (Hair et al., 2006) [23] theory, which is 5 or 10 times the number of indicators. The research indicators are 20 , so the minimum sample is $5 \times 20=100$ samples. In this study, there were 124 respondents, in which questionnaires were distributed via google form and carried out by judgment sampling and snowball techniques, by distributing questionnaires based on certain considerations and spreading from respondents to respondents.

\section{Results and Discussion}

\subsection{Profile of Respondent}

Analysis of respondents showed that the majority of 120 respondents $(96.8 \%)$ used mobile payment application services (m-payment), while 2 respondents $(1.6 \%)$ did not use them and 2 other respondents $(1.6 \%)$ chose to be interested in using them. Age of respondents, $21-30$ years old as much as $41.1 \%$, 31-40 years as much as $47.6 \%$, while the rest aged 41-50 years as much as 9.7\%, and over 50 years old as much as $1.6 \%$. Respondents' behavior in using various m-payment applications varies. 
The order of using the m-payment application by respondents, among others: the use of GoPay and OVO was chosen by 16 respondents (13\%). The use of GoPay, OVO, Funds was 15 respondents $(12 \%)$. The use of GoPay alone was 14 respondents (11\%). LinkAja, Gopay, OVO as many as 13 respondents (10\%), then LinkAja, GoPay, OVO users, funds as many as 13 respondents $(10 \%)$ the remaining $1 \%$ to $4 \%$ of respondents used a combination of applications from fintech and banking. This shows that competition among m-payment application companies is very tight considering m-payment users can make its choice freely with the many m-payment companies in this industry. Therefore, the factors that influence the interest in using m-payment need attention from these companies.

\subsection{Result of Validity and Reliability Test}

The results of the validity test show that all indicators are declared valid because the corrected item values of all indicators are more than the r-table value (0.176). Thus, it means that all indicators are able to represent the independent variable and the dependent variable being tested. Reliability test results show that all variables Cronbach's Alpha value are above 0.6. Thus, all variables are declared reliable. Likewise, the normality test, multicollinearity, and heterogeneity tests show that the data collected for further processing has met the requirements.

Table 1. Validity Test

\begin{tabular}{|c|c|c|c|}
\hline $\begin{array}{l}\text { Number of Item } \\
\text { (SPSS) }\end{array}$ & $\begin{array}{l}\text { Corrected Item- } \\
\text { Total Correlation }\end{array}$ & $\mathbf{r}_{\text {table }}$ & Result \\
\hline \multicolumn{4}{|c|}{ Perceived Ease of Use (X1) } \\
\hline MD1 The system is clear and easy to understand & 0.494 & 0,176 & Valid \\
\hline MD2 It doesn't take much effort & 0.630 & 0,176 & Valid \\
\hline MD3 The system is easy to use & 0.431 & 0,176 & Valid \\
\hline MD4 The system is flexible & 0.603 & 0,176 & Valid \\
\hline MD5 Easy to top up/refill & 0.235 & 0,176 & Valid \\
\hline \multicolumn{4}{|c|}{$\begin{array}{ll}\text { Perceived Usefulness (X2) } \\
\end{array}$} \\
\hline MF6 Improve the performance & 0.689 & 0,176 & Valid \\
\hline MF7 Increase the level of productivity & 0.781 & 0,176 & Valid \\
\hline MF8 Improve performance effectiveness & 0.758 & 0,176 & Valid \\
\hline MF9 Useful system & 0.771 & 0,176 & Valid \\
\hline \multicolumn{4}{|c|}{ Perceived Mobility (X3) } \\
\hline MB10 Can be used at any time & 0.733 & 0,176 & Valid \\
\hline MB11 Can be used anywhere & 0.834 & 0,176 & Valid \\
\hline MB12 While traveling, can still use the apps & 0.721 & 0,176 & Valid \\
\hline \multicolumn{4}{|c|}{ Perceived Trust (X4) } \\
\hline $\begin{array}{l}\text { KP13 The belief that the application provider does } \\
\text { not disclose the privacy information of its users }\end{array}$ & 0.790 & 0,176 & Valid \\
\hline $\begin{array}{l}\text { KP14 Trust that application providers keep their user } \\
\text { data safe }\end{array}$ & 0.894 & 0,176 & Valid \\
\hline $\begin{array}{c}\text { KP15 Trust in technological developments through } \\
\text { the use of applications }\end{array}$ & 0.663 & 0,176 & Valid \\
\hline $\begin{array}{l}\text { KP16 Trust in the application will not loss the users } \\
\text { finances }\end{array}$ & 0.804 & 0,176 & Valid \\
\hline KP17 Trust that funds / money stored are safe & 0.828 & 0,176 & Valid \\
\hline \multicolumn{4}{|c|}{ Intention to use M-Payments (Y) } \\
\hline PM18 Intention to use m-payments & 0.768 & 0,176 & Valid \\
\hline $\begin{array}{l}\text { PM19 Planning will be more frequent in the use of } \\
\text { m-payments }\end{array}$ & 0.906 & 0,176 & Valid \\
\hline PM20 Continuous intensity in using m-payments & 0.851 & 0,176 & Valid \\
\hline
\end{tabular}


Table 2. Reliability Test

\begin{tabular}{cccc}
\hline Variable & $\begin{array}{c}\text { Cronbach' } \\
\text { s Alpha }\end{array}$ & $\begin{array}{c}\text { N of } \\
\text { Item }\end{array}$ & Result \\
\hline Perceived Ease of Use (X1) & 0,649 & 5 & Reliable \\
Perceived Usefulness (X2) & 0,878 & 4 & Reliable \\
Perceived Mobility (X3) & 0,871 & 3 & Reliable \\
Perceived Trust (X4) & 0,916 & 5 & Reliable \\
Intention to use M-Payments (Y) & 0,920 & 3 & Reliable \\
\hline
\end{tabular}

\subsection{Result of F Test, T Test, Correlation Test}

Based on the results of the $F$ test, the results of this study indicate that the independent variables jointly and partially affect customer interest in using m-payments significantly and positively. The following is an $\mathrm{F}$ test table, T-test table and picture of the research result model.

Table 3. F Test Results

\begin{tabular}{|l|l|r|r|r|r|r|}
\hline \multicolumn{2}{|l|}{ Model } & Sum of Squares & Df & Mean Square & \multicolumn{1}{c|}{$\mathrm{F}$} & \multicolumn{1}{c|}{ Sig. } \\
\hline \multirow{4}{*}{1} & Regression & 59.651 & 4 & 14.913 & 79.467 & $.000^{\mathrm{b}}$ \\
\cline { 2 - 8 } & Residual & 22.331 & 119 & .188 & & \\
\cline { 2 - 8 } & Total & 81.982 & 123 & & & \\
\hline
\end{tabular}

a. Dependent Variable: Intention to Use M-Payment ( $Y$ )

b. Predictors: (Constant), Perceived Trust (X4), Perceived Mobility (X3), Perceived Usefulness (X2), Perceived

Ease of Use (X1)

Table 4. T Test Results

\begin{tabular}{|c|c|c|c|c|c|c|}
\hline & & \multicolumn{2}{|c|}{$\begin{array}{c}\text { Unstandardized } \\
\text { Coefficients }\end{array}$} & \multirow{2}{*}{$\begin{array}{c}\begin{array}{c}\text { Standardized } \\
\text { Coefficients }\end{array} \\
\text { Beta } \\
\end{array}$} & \multirow[b]{2}{*}{$\mathrm{T}$} & \multirow[b]{2}{*}{ Sig. } \\
\hline \multicolumn{2}{|c|}{ Model } & $B$ & Std. Error & & & \\
\hline \multirow[t]{5}{*}{1} & (Constant) & -.947 & .345 & & -2.746 & .007 \\
\hline & Perceived Ease of Use $\left(X_{1}\right)$ & 192 & .080 & .174 & 2.385 & .019 \\
\hline & Perceived Usefulness $(\mathrm{X} 2)$ & .340 & .074 & .313 & 4.609 & .000 \\
\hline & Perceived Mobility $(\times 3)$ & .337 & .077 & .335 & 4.378 & .000 \\
\hline & Perceived Trust (X4) & .319 & 051 & .307 & 6.227 & .000 \\
\hline
\end{tabular}

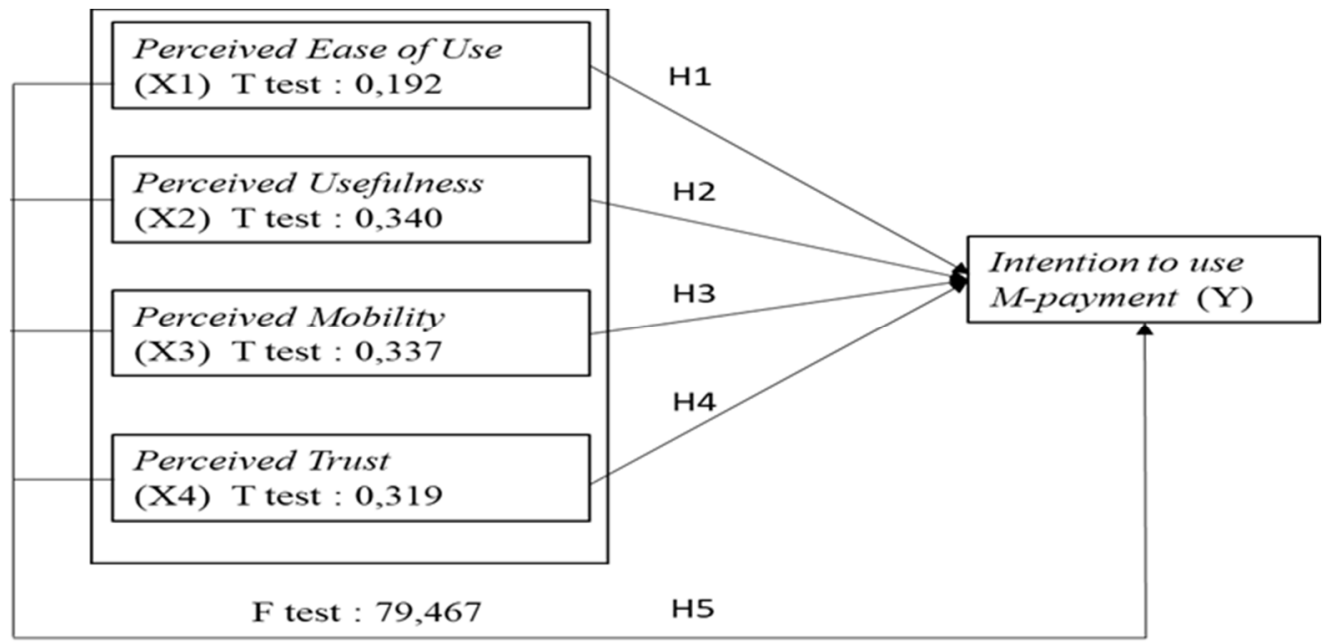

Fig 1. Research Results Model 
Based on the results of the $\mathrm{T}$ test, all the independent variables in this research have significantly and positively affects to the dependent variable (intention to use m-payment). The perceived ease of use variable affects values is $0.192(19.2 \%)$. This means that if the mpayment application provides convenience (ease of use), it will affect the interest in using the m-payment application by $19.2 \%$, and then the perceived usefulness variable affects value is $0.340(34.0 \%)$. The following shows the results of the correlation test between the variables, this table of the relationship between the independent and the dependent variable will use for further analysis and discussion.

Table 5. Correlation Test Results between Variables

\begin{tabular}{|c|c|c|c|c|c|c|}
\hline \multirow[b]{3}{*}{ No. } & \multirow[b]{3}{*}{ Variable } & \multirow[b]{3}{*}{ Indicator } & \multirow[b]{3}{*}{ Code } & \multicolumn{3}{|c|}{ Intention to use $M$-payment $(\mathrm{Y})$} \\
\hline & & & & PM18 & PM19 & PMzO \\
\hline & & & & $\begin{array}{l}\text { Intention to } \\
\text { use m- } \\
\text { payments }\end{array}$ & $\begin{array}{l}\text { Planning } \\
\text { will be } \\
\text { more } \\
\text { frequent } \\
\text { in the use } \\
\text { of m- } \\
\text { payments }\end{array}$ & $\begin{array}{l}\text { Continuous } \\
\text { intensity in } \\
\text { using m- } \\
\text { payments }\end{array}$ \\
\hline \multirow{5}{*}{1} & \multirow{5}{*}{ Perceived Ease Of use (X1) } & $\begin{array}{l}\text { The system is clear and } \\
\text { easy to understand }\end{array}$ & MD1 & 0.556 & 0.493 & 0.383 \\
\hline & & $\begin{array}{l}\text { It doesn't take much } \\
\text { effort }\end{array}$ & MD2 & 0.568 & 0.452 & 0.432 \\
\hline & & The system is easy to use & MD3 & 0.467 & 0.409 & 0.408 \\
\hline & & The system is flexible & MD4 & 0.538 & 0.358 & 0.483 \\
\hline & & Easy to top up/refill & MD5 & 0.462 & 0.385 & 0.484 \\
\hline \multirow{4}{*}{2} & \multirow{4}{*}{ Perceived Usefulness (X2) } & Improve the performance & MF6 & 0.576 & 0.576 & 0.424 \\
\hline & & $\begin{array}{l}\text { Increase the level of } \\
\text { productivity }\end{array}$ & MF7 & 0.530 & 0.523 & 0.473 \\
\hline & & $\begin{array}{l}\text { Improve performance } \\
\text { effectiveness }\end{array}$ & MF8 & 0.540 & 0.469 & 0.418 \\
\hline & & Useful system & MF9 & 0.541 & 0.569 & 0.394 \\
\hline \multirow{3}{*}{3} & \multirow{3}{*}{ Perceived Mobility (X3) } & Can be used at any time & мB10 & 0.598 & 0.530 & 0.491 \\
\hline & & Can be used anywhere & MB11 & 0.624 & 0.434 & 0.470 \\
\hline & & $\begin{array}{l}\text { While traveling, can still } \\
\text { use the apps }\end{array}$ & Мв12 & 0.616 & 0.543 & 0.521 \\
\hline \multirow{5}{*}{4} & \multirow{5}{*}{ Perceived Trust (X4) } & $\begin{array}{l}\text { The belief that the } \\
\text { application provider } \\
\text { does not disclose the } \\
\text { privacy information of } \\
\text { its users }\end{array}$ & KP13 & 0.335 & 0.384 & 0.345 \\
\hline & & $\begin{array}{l}\text { Trust that application } \\
\text { providers kecp their user } \\
\text { data safe }\end{array}$ & KP14 & 0.336 & 0.328 & 0.345 \\
\hline & & $\begin{array}{l}\text { Trust in technological } \\
\text { developments through } \\
\text { the use of applications }\end{array}$ & KP15 & 0.304 & 0.273 & 0.359 \\
\hline & & $\begin{array}{l}\text { Trust in the application } \\
\text { will not loss the users } \\
\text { finances }\end{array}$ & KP16 & 0.306 & 0.303 & 0.332 \\
\hline & & $\begin{array}{l}\text { Trust that funds / money } \\
\text { stored are safe }\end{array}$ & KP17 & 0.280 & 0.395 & 0.359 \\
\hline
\end{tabular}

The independent variables in this research have significantly and positively affected to the dependent variable (intention to use m-payment). The perceived ease of use variable affects values is $0.192(19.2 \%)$. This means that if the m-payment application provides convenience (ease of use), it will affect the interest in using the m-payment application by $19.2 \%$, and then the perceived usefulness variable affects value is $0.340(34.0 \%)$. This means that if the m-payment application provides more benefits to the users, it will affect the interest in using the m-payment application by $34.0 \%$. The perceived mobility variable affects value is $0.337(33.7 \%)$.

This means that if the m-payment application provides the mobility to users, it will affect the interest in using the m-payment application by $33.7 \%$, and then the perceived trust variable affects value is $0.319(31.9 \%)$. This means that if the m-payment application can make the users trust the apps, it will affect the interest in using the m-payment application by $31.9 \%$. 
The ease-of-use variable affects the interest in using the application, according to the results of previous research (Fitri and Wulandari 2020 [12]; Liu et al. 2019 [4]; Rahim 2019 [13]; Meiranto, 2016 [14]; Mandariza et al. 2019 [15]; Chandra et al. 2018 [6]; Trivedi 2016 [7]). In addition, there are 3 indicators of the perceived ease of use variable or X1 which has the highest correlation to variable $\mathrm{Y}$, namely the indicator ssystem is clear and easy amounting to $0.556(55.6 \%)$, the indicator does not need a lot of effort in using mobile payment applications amounted to $0.568(56.8 \%)$, and the flexible indicator was 0.538 $(53.8 \%)$. This means that mobile payment management must maintain ease of use and create a flexible system so that the mobile payment application can attract the interest of its users. Thus, GoPay, which was ranked first in the m-payment industry, or LinkAja, which was down in ranking, as well as other companies need to innovate so that a clear system is easy, does not require a lot of effort, and is flexible, in their application so that it always meets the requirements of consumer needs that are always changing.

The variable of perceived usefulness significantly and positively affects the interest in using m-payments, which is $0.34(34.0 \%)$. This means that if the m-payment application provides usefulness, it will affect the interest in using the m-payment application by $34 \%$. The usefulness variable has a significant and positive effect on interest in using applications, according to the results of previous research (Fitri and Wulandari 2020 [12]; Liu et al. 2019 [4]; Rahim 2019 [13]; Meiranto, 2016 [14], Mandariza et al. 2019 [15]; Chandra et al. 2018 [6]; Arfan and Mirza, 2020 [24]). In addition, there are two indicators of perceived usefulness or $\mathrm{X} 2$ variables that have the highest correlation to the two Y variables, namely applications that can increase performance by $0.576(57.6 \%)$, a useful system of 0.569 $(56.9 \%)$. This means that the management of $\mathrm{m}$-payment application owners, including GoPay, OVO, LinkAja, Dana and, others, need new breakthroughs and innovations in order to always upgrade the application to have the best performance, and provide more benefits to its users.

The variable perception of mobility has a significant and positive effect on the interest in using m-payment, which is $0.337(33.7 \%)$. This means that if the m-payment application provides space for mobility, it will affect the interest in using the m-payment application by $33.7 \%$. The mobility variable has a significant and positive effect on the interest in using the application, according to the results of previous studies (Liu, et al. 2019 [4]; Chandra, et al. 2018 [6]; Schierz, et al. 2010 [18]). In addition, there are two indicators of the variable perception of mobility (mobility) or the X3 variable which has the greatest correlation value to variable Y, namely the application can be used at any time of $0.624(62.4 \%)$, and the indicator when traveling the application can still be used at 0.616. (61.6\%).

This means that m-payment management needs to maintain the availability and service quality of its application system so that it can be used by users anywhere, also when traveling, the application can be used properly, including in areas where the signal is not good. Business actors in the m-payment industry need to innovate to provide useful services.

The perception variable of trust has a significant and positive effect on the interest in using m-payment, which is $0.319(31.9 \%)$. This means that if the m-payment application causes the emergence of trust, then the interest in using the m-payment application will be affected by $31.9 \%$. The trust variable has a significant and positive effect on the interest in using the application, according to the results of previous research (Mandariza et al. 2019 [15]; Fan, et al. 2018 [21]; Ahmad, et al. 2016 [5]; Yang, 2015 [22]; Arfan and Mirza, 2020 $[24])$.

On the other hand, there are two indicators of the trust variable (trust) or variable $\mathrm{X} 4$ which have the highest correlation value to variable $\mathrm{Y}$, namely the belief that funds are 
stored safely of $0.395(39.5 \%)$, and indicators of trust that application providers do not disseminate privacy information. users of $0.384(38.4 \%)$. This means that management in the m-payment industry needs to maintain the security of the system and its application so that it is not easily hacked, so that it is detrimental to customer funds and customer data. Thus, continuous innovation is needed to strengthen the application system, so that customers feel comfortable so that they have a high perception of confidence in the security of funds and data.

\section{Conclusions}

The results show that there is a significant and positive influence between perceived ease of use, perceive usefulness, perceive of mobility, and perceive of trust on interest in using mobile payments. The basic concept of the TAM Theory is 2 variables of behavior and consumer perceptions of technological change, namely perceived ease of use, perceive usefulness. The results of this study are the development of this theory by adding perceive mobility and perceived trust as behaviors and perceptions that affect the interest in using changes in technology, in this case mobile payment technology.

The relationship between indicators shows that m-payment application companies need to pay attention to the following some strategic points to meet the need for increasing perceptions of ease of use, it is necessary to maintain and develop a system that is clear, easy, does not require a lot of effort, and is flexible. To maintain the perceived needs of benefit, companies need to make new breakthroughs and innovations to constantly upgrade their applications to have the best performance and provide more benefits to their users. About the perceive of mobility, it is necessary to maintain the application so that it can be used anywhere, including in areas where the signal is not good and then to maintain the perceive of trust, it is necessary to continuous innovation so that the system cannot be hacked to meets the security of customers funds and data.

This research can be further developed by exploring other variables of consumer behavior besides the variables used in this study. The trust variable needs to be used in further research, because some previous researchers have shown that the trust variable does not affect the intention to use m-payment, or the risk variable, because in previous studies, the risk variable has no effect on the interest in using digital technology in online sales transactions.

\section{References}

[1] Admin, "Mobile payments in Indonesia Race to Big Data Domination". MDI Ventures [Online], march 5 2018, available: https://www.mdi.vc/whitepaper/detail/3/Mobile\% 20Payments\%20In\%20Indonesia\%3A\%20Race\%20to\%20Big\%20Data\%2Domination (accessed on 23 December 2019).

[2] D. Vivin Dian, "Siapa Aplikasi E-wallet dengan Pengguna Terbanyak di Indonesia?". Iprice Group [Online], august 12 2019, available: https://iprice.co.id/trend/insights/e-wallet-terbaikdi-indonesia (accessed on 23 Desember 2019)

[3] A. Arbi, "Bayar Tanpa Cash Bisa Cegah Penularan Virus Corona". Detik Finance [Online] march 152020 available: https://finance.detik.com/moneter/d-4939960/bayar-tanpa-cash-bisacegah-penularan-virus-corona. (accessed on 9 Agustus 2020).

[4] Liu, Y., Wang, M., Huang, D., Huang, Q., Yang, H., \& Li, Z.,’The impact of mobility, risk, 
and cost on the users' intention to adopt mobile payments". Information Systems and eBusiness Management, 1-24, 2019.

[5] Ahmad, ABH, Ismail, YB, \& Kadir, MFB., "Review of customer adoption on mobile payment". Journal of Postgraduate Current Business Research, 1 (2). 2016.

[6] Chandra, YU, Kristin, DM, Suhartono, J., Sutarto, FS, \& Sung, M., "Analysis of determinant factors of user acceptance of mobile payment system in Indonesia (A Case Study of Go-Pay Mobile Payment)". in conf. 2018 International Conference on Information Management and Technology (ICIMTech). pp. 454-459. September, 2018.

[7] Trivedi, J., "Factors determining the acceptance of e-wallets". International Journal of Applied Marketing and Management, 1 (2), 42-53. 2016.

[8] Davis, FD., "Perceived usefulness, perceived ease of use, and user acceptance of information technology". MIS Quarterly. 319-340. 1989.

[9] Jogiyanto. Behavioral information system. Revised Edition. Yogyakarta: AndiOffset. 2007.

[10] Adamson, I., \& Shine, J., "Extending TAM to measure end user computer satisfaction in a mandatory environment: a bank's treasury". Technology Analysis and Strategic Management Journal, 15 (4), 441-454. 2003.

[11] Venkatesh, V. Morris et al., "User acceptance of information technology: toward a unified view". MIS Quartely. Vol. 27 No. 3: pg. 425-478. 2003.

[12] Fitri, R. \& Wulandari, R., "Online purchase intention factors in Indonesian millenial", International Review of Management and Marketing, Vol. 10. No. 3. 2020.

[13] Rahim, H., "Analysis of the influence of perceptions of risk, and trust on transaction interest using paytren at PT. Veritra Sentosa International”. Journal of Ecobist and Technology, 6 (2). 2017.

[14] Meiranto, W., "Analysis of factors influencing interest in the use of mobile electronic payment technology using the main model (case study on the m-dinar payment system technology)". Indonesian Journal of Accounting, 1 (1), 50-60. 2016.

[15] Mandariza, A., Furkan, LM, \& Mulyono, LEH., "Factors that influence consumer perceptions of the use of electronic payment (server based)". Jmm Unram-unram Management Review, 8 (4), 378-392. 2019.

[16] Pal, D., Vanijja, V., \& Papasratorn, B., “An empirical analysis towards the adoption of NFC mobile payment system by the end user". Procedia Computer Science, 69, 13-25. 2015.

[17] Tai, PT, \& Liu, GS., "An analysis of factors affecting the intention to use mobile payment services in Vietnam". In Proceedings of the Second Asia-Pacific Conference on Global Business, Economics, Finance and Social Sciences. pp. 1-21. 2015.

[18] Schierz, PG, Schilke, O., \& Wirtz, BW., "Understanding consumer acceptance of mobile payment services: An empirical analysis". Electronic commerce research and applications, 9 (3), 209-216. 2010.

[19] Gefen, David., Karahanna, Elena and Straub, Detmar W., "Trust And TAMIn Online Shopping: An Integrated Model. March. MIS Quarterly. 2003.

[20] Ba, S. and Pavlou, PA, "Evidence of the effect of trust building technology in electronic markets: price premiums and buyer behavior". MIS Quarterly, Vol. 26, No. 3. 2002

[21] Fan, J., Shao, M., Li, Y., \& Huang, X., "Understanding users' attitude toward mobile payment use: A comparative study between China and the USA". Industrial Management \& Data Systems, 118 (3), 524-540. 2018.

[22] Yan, H., \& Yang, Z., "Examining mobile payment user adoption from the perspective of trust". International Journal of u-and e-Service, Science and Technology, 8 (1), 117-130. 2015.

[23] Hair, Joseph F Jr., WCBlack., BJ Babin. and R. E. Anderson., Multivariate Data Analysis: a Global Perspective, 5th ed., Pearson Prentice Hall. New Jersey. 2010.

[24] Arfan A., Mirza, " Factors That Influence the Use of Online Ticket Application (Case Study: Traveloka)", International Journal of Innovative Science and Research Technology, Vol. 5, Issue 7, July, 2020. 